\title{
TRAINING AND PERCEPTION OF ASSESSMENT PRACTICES OF EARLY CHILDHOOD TEACHERS IN THE TEMA WEST METROPOLIS, GHANA
}

\author{
Agnes Amoah ${ }^{1}$, \\ Yayra Dzakadzie ${ }^{2 i}$, \\ Seth Agbayisah ${ }^{3}$ \\ ${ }^{1}$ Aggrey Road School Complex, \\ Tema Community Two, \\ Ghana \\ 2Department of Early Childhood Education, \\ Faculty of Educational Studies, \\ University of Education, \\ Winneba, Ghana \\ ${ }^{3}$ Agogo Presbyterian Women College of Education, \\ Akyem-Agogo, Ghana
}

\begin{abstract}
:
The study sought to assess the training and perception of assessment practices of Early Childhood Education teachers in the Tema West Metropolis, Ghana. Two research objectives guided the study and they were to assess the training of Early Childhood Education teachers and examine the teachers' perception about assessment during early years' education as well as the professional qualification and gender differences of teachers' perception in the Tema West Metropolis, Ghana. Again, two hypotheses were formulated to guide the study. A descriptive survey design was used for the study. The instrument for data collection was a self-constructed 4-point Likert-type scale questionnaire. The study covered 200 ECE teachers within 40 basic schools in the Tema West metropolis. The census technique was used to select the participants for the study. Descriptive statistics (mean and standard deviation) were used to analyze data obtained with respect to each research question. Again, One Way ANOVA and Independent sample T-test were used to test hypothesis 1 and 2 respectively. It was evidenced from the study that the teachers in the Tema West Metropolis have an understanding of Early Childhood Education (ECE) assessment practices which suggests an indication that the teachers have some level of training. Again, ECE teachers in the metropolis possess positive perceptions about the need for assessing children during their early years' education. While the perception of ECE teachers differs significantly across their professional qualifications, there was no statistically significant difference in their perception about assessment in early years' education and gender. The study concludes
\end{abstract}

'Correspondence: email dyayra2014@gmail.com 
therefore that training and perception of ECE teachers were no deterrents nor challenges to the administration of effective assessment practices in the Tema West Municipality. Although the teachers possess some level of knowledge about assessment practices in ECE, it is recommended among others that the educational directorate in the metropolis through the help of the Ghana Education Service (GES) should ensure continuous professional development in the form of in-service training for the teachers. This will help abreast their knowledge and assessment practices in the metropolis.

Keywords: assessment, practices, early childhood education, perception, training

\section{Introduction}

The role of assessment in the education of children cannot be underestimated and this makes Early Childhood Education assessment very crucial for educational studies. Dunphy (2010) emphasized that assessment has a growing reputation among educators at all levels of education which includes early years' education. Studies conducted by Bowman, Donovan, and Burns (2001) and Schappe (2005) indicated that teaching and assessment in the early years are considered to have an important place as it is in other levels of education systems. Assessment during early years education therefore must be given out the most attention and consideration.

Ellis (2014) defines assessment as a systematic process to measure or evaluate the characteristics or performance of individuals, programs, and entities for the purposes of drawing inferences. In a similar vein, Goodwin (2000) defined assessment as the process of determining through observation or testing, an individual's traits or behaviours, a program characteristic, or the properties of some other entity and then assigning a number, rating, or score to that determination. Hills cited in Bronson (1994) stated that early childhood assessment involves multiple steps of collecting data on children's development and learning, determining its significance in light of the programme goals and objectives, incorporating the information into planning for individuals and programme, and communicating the findings to parents and others. From the definitions, it could be established that assessment of young learners is different from the assessment of older learners, therefore, assessment of young learners should involve multiple and variety of approaches in order to generate a comprehensive understanding of young learners' skills and needs.

According to Horton and Bowman (2002), understanding the need for early years assessment and the way assessment practices are carried out during early years' education will improve the learning and development of young children. Amponsah (2004) emphasized that the importance and purpose of assessment during earlier years of education is to provide adults with the information they need to plan more appropriately for children's ongoing development, and therefore it needs to involve strategies that support rather than threaten children's feelings of self-esteem. Several studies revealed the importance of assessment, especially during the early years of 
education. Among these, relevance are to monitor children's learning and development progress, helps in making decisions about programmes to advance learning and development, helps in identifying children who may benefit from special support or intervention, helps in communicating a child's learning and development with families and other professionals helps in involving families in planning children's learning in a meaningful way and helps in evaluating early childhood programmes' effectiveness (Bagnato, McLean, Macy \& Neisworth, 2011; Copple \& Bredekamp 2006; Puckett and Black 2000; Trevarthen, 2002).

The availability of qualified and trained teachers is vital in the provision of developmentally appropriate assessment practices in ECE centres. This is because teachers play very crucial roles in the development and learning of children during their early years. The quality of an educational system, therefore, depends on the quality of its teachers (Soto \& Swadener, 2002). Siegel (1987) stated that due to the many functions performed by the ECE teacher; he/she must possess a certain quality of education, greater theoretical knowledge of child development and learning.

Teachers' qualification corresponds positively with the teaching and learning of children in many studies. For instance, Betts, Zau, and Rice (2003) found that teachers' qualification correlates fairly positively with children's learning and assessment. Betts et al submitted that, when teachers have an advanced degree in their teaching subjects or specializations, it has a positive impact on the children's learning and achievement. In the same vein, Khurshid (2008) also observed that, if a specially trained teacher teaches a group of learners, the performance of the learners was good and high because, in the process of education, the teacher is very crucial. Forrester, (2008) stated that teachers' knowledge about the subject to be taught certainly affects their teaching attitude and eventually the performance of the learners.

Teachers' perceptions about assessment in Early Childhood Education have been investigated by several researchers in many different ways and have come out with several findings. Fennema and Romberg (1999) indicate that the way teachers perceive assessment may influence the way they teach and assess their students. Chester and Quilter (1998) also believed that studying teachers' perceptions and practices of assessment is vital in the sense that it provides an indication of how different forms of assessment are being used or misused and what could be done to improve the situation. Chester and Quilter further stated that teachers' perceptions of classroom assessment affected their classroom assessment practices. Thus, teachers who attached less value to classroom assessment used standardized tests most of the times in their classrooms. Also, teachers with negative experiences in classroom assessment and standardized testing are less likely to see the value and the need for various forms of classroom assessments for learners (Chester and Quilter, 1998).

Cavangah, Waldrip, Romanoski, Fisher, and Dorman (2005) indicated that assessment forms and tasks selected by teachers and administrators depend on their perceptions of assessment. Roos and Hamilton (2005) therefore cautioned that teachers must perceive the value of assessment to go far beyond playing a role in the self- 
regulation of human learning but also being able to support human development. Sokopo (2004) found that teachers essentially believed that classroom assessment is merely for the accumulation of marks and this causes curricular outcomes to be reduced to a checklist. However, Gulikers, Bastiaens, Kirshner, and Kester (2006) as well as Pelligrino and Goldman (2008) revealed that teachers greatly believe that assessment significantly affects students' approach to learning.

It could be deduced from the ongoing argument that in order to ensure effective teaching, learning, and appropriate assessment practices at Early Childhood Education centres, one must first meet the needs of trained teachers who have a positive perception and knowledge about how children learn and how they can be assessed. This is, however, contrary in most early childhood schools in Africa including Ghana especially in private owned early childhood schools, where teachers with no training in ECE are often found in children's classrooms (Okewole, Iluezi- Ogbedu, \& Osinowo, 2015; Osho, Aliyu, Okolie, \& Onifade; 2013; Williams, 1996).

Although, training and perception of teachers cannot be ignored as far the assessment of children during their early years' education is concerned, little has been known and documented on the training and perception of teachers who deliver Early Childhood Education programme in the Tema West Metropolis and how it influences their assessment practices. Earlier studies conducted on assessment of children do not investigate nor do they report on the level of training and the perception of teachers as well as the influence these elements have on their assessment practices in the Tema West Metropolis, Ghana. One may then ask, do the teachers who deliver Early Childhood Education have the needed training to assess children in the study area? What is the perception of teachers about assessing children during their early years' education? Does the training and perception of teachers influence the assessment practices of teachers in the study area? Answers to these questions are not readily available in the current literature. This study was therefore conducted to assess the training and perception of assessment practices of early childhood teachers in the Tema West Metropolis, Ghana.

\section{Research Objectives}

The study sought to:

1) Assess the training of Early Childhood Education teachers in the Tema West Metropolis, Ghana.

2) Examine teachers' perception about assessment during early years' education as well as the professional qualification and gender differences of teachers' perception in the Tema West Metropolis, Ghana.

\subsection{Research Questions}

The study was guided by the following questions:

1) What is the training of Early Childhood Education teachers in the Tema West Metropolis, Ghana? 
2) What is the perception of teachers about assessment during early years' education in the Tema West Metropolis, Ghana?

\subsection{Hypotheses}

$\mathbf{H}_{0}$ 1: There is no statistically significant difference in the perception of ECE teachers about early childhood assessment and their professional qualification in the Tema West Metropolis.

$H_{1}$ 1: There is a statistically significant difference in the perception of ECE teachers about early childhood assessment and their professional qualification in the Tema West Metropolis.

$\mathbf{H}_{0}$ 2: There is no statistically significant difference in the perception of male and female ECE teachers about early childhood assessment the Tema West Metropolis.

$\mathbf{H}_{1}$ 2: There is a statistically significant difference in the perception of male and female ECE teachers about early childhood assessment the Tema West Metropolis.

\section{Methodology}

A descriptive survey research design was adopted and used for the study. Measurement of variables of interest occurred at a time and there was no attempt to manipulate any of the variables measured in this study. The study targeted all Basic schools and all the ECE teachers. The accessible population was made up of 40 Basic Schools and 200 Early Childhood Education teachers. The census technique was used to select the participants for the study. This implies that all Basic schools and ECE teachers were used for the study. The instrument of data collection was a self-constructed 4-point Likert-type scale questionnaire. There were two sections on the questionnaire. Items in section A were used to elicit data on the training of teachers and section $\mathrm{B}$ elicit responses on the perception of teachers about assessment in ECE. There were eight (8) items in section A and six (6) items in section B of the questionnaire. The rating format ranges from "strongly agree" (4) to "strongly disagree" (1). Cronbach's alpha coefficient was used to determine the consistency of the instrument. The result of the reliability alpha coefficient for the instrument was .748 indicating that the instrument met the threshold to be used for the study (Dörnyei \& Taguchi, 2010). Descriptive statistics (mean and standard deviation) were used to analyze data obtained with respect to each research question. Again, One Way ANOVA and Independent sample T-test were used to test the hypothesis raised for the study respectively.

\section{Results}

\subsection{Level of Training of Early Childhood Education Teachers}

The first research question "What is the training of Early Childhood Education teachers in the Tema West Metropolis, Ghana?" sought to ascertain the level of training of teachers who deliver Early Childhood Education programme in the Tema West Metropolis. 
Professional qualifications of teachers were ascertained as part of the level of training of teachers. The results of the professional qualification were presented in Table 1, analyzed using frequency and percentages, and data for research question 1 was analyzed using Mean and Standard deviation and presented in Table 2.

Data in Table 1 indicates that $63(31.5 \%)$ of the respondent had a Bachelor of Education in Early Childhood Education while 46 (23.0\%) had a Diploma in Early Childhood Education. 56 (28.0\%) of the respondents had a Diploma in Basic Education while 18 (9.0\%) had Bachelor in Basic Education. 17 (8.5\%) respondents however possess Teacher Certificate ' $A$ '. Data presented in the table suggest that majority of the respondents in the Tema West Metropolis used for the study specialized in Early Childhood Education.

Table 1: Professional Qualification of Respondents

\begin{tabular}{|l|c|c|}
\hline Professional Qualification & Frequency (F) & Percent (\%) \\
\hline Teachers Certificate 'A' & 17 & 8.5 \\
\hline Diploma in Early Childhood Education & 46 & 23.0 \\
\hline Diploma in Basic Education & 56 & 28.0 \\
\hline Bachelor of Education (Early Childhood) & 63 & 31.5 \\
\hline Bachelor in Basic Education & 18 & 9.0 \\
\hline Total & $\mathbf{2 0 0}$ & $\mathbf{1 0 0 . 0}$ \\
\hline Source: Field Data, 2021. & \multicolumn{2}{|l}{} \\
\hline
\end{tabular}

Table 2: Analysis of the Training of Teachers

\begin{tabular}{|l|c|c|}
\hline Statement & Mean & SD \\
\hline $\begin{array}{l}\text { Trained on assessment within the context of Early Childhood } \\
\text { Education. }\end{array}$ & 3.46 & .708 \\
\hline $\begin{array}{l}\text { The purpose of ECE assessment is to determine whether pupils } \\
\text { have mastered a learning objective. }\end{array}$ & 3.50 & .634 \\
\hline $\begin{array}{l}\text { Early Childhood Education assessment should be } \\
\text { age-appropriate. }\end{array}$ & 3.60 & .558 \\
\hline $\begin{array}{l}\text { Assessment during early years education should be linguistically } \\
\text { appropriate. }\end{array}$ & 3.43 & .615 \\
\hline $\begin{array}{l}\text { Giving appropriate comments for pupils' assessment results in ECE } \\
\text { is more important than giving grades or marks. }\end{array}$ & 3.68 & .497 \\
\hline $\begin{array}{l}\text { Parents are a valuable source of information for children's assessment } \\
\text { during their early years. }\end{array}$ & 3.56 & .615 \\
\hline $\begin{array}{l}\text { Early childhood assessment is to just prepare children for standardized } \\
\text { examinations. }\end{array}$ & 3.19 & .903 \\
\hline $\begin{array}{l}\text { Early childhood assessment helps pupils to make account of their } \\
\text { learning progress. }\end{array}$ & 3.36 & .635 \\
\hline Mean of Means and Standard Deviation & 3.47 & .352 \\
\hline SD = Standard Deviation. & & \\
\hline
\end{tabular}

Comparing the average mean or mean of means (3.47) and a corresponding standard deviation (.352) with the individual means of the respective items (statements), it could be seen from Table 2 that the means for the statements "the purpose of ECE assessment 
is to determine whether pupils have mastered a learning objective" $($ Mean $=3.50$; $\mathrm{SD}=$ .634), "ECE assessment should be age-appropriate" (Mean = 3.60; SD = .558), "giving appropriate comments for pupils' assessment results in ECE is more important than giving grades or marks" (Mean $=3.68$; $\mathrm{SD}=.497)$ and "parents are a valuable source of information for children assessment during their early years" (Mean $=3.56$; SD $=.615$ ) are higher than the calculated mean of means of 3.47. This result implies that the teachers used for the study in the Tema West Metropolis have strongly agreed to these statements which suggest that they have received some level of training and hence possess knowledge and understanding of assessment within Early Childhood Education. Table 2 again indicated that the teachers were in agreement that they have been trained on assessment within the context of Early Childhood Education (Mean = 3.46; SD = .708), assessment during early years education should be linguistically appropriate (Mean = $3.43 ; \mathrm{SD}=.615$ ) and help pupils to make account of their learning progress (Mean = 3.36; $\mathrm{SD}=.635)$. These responses from the teachers further suggest that the teachers have some level of understanding of children's assessment which is an indication that they have some level of training. It was however interesting to indicate that despite demonstrating that they have been trained, ECE teachers at the Tema West Metropolis still perceive and believe the negative assumption that ECE assessment is just to prepare learners for external examination. This was evidenced as the teachers agreed that early childhood assessment is to just prepare children for standardized examinations (Mean = 3.19; $\mathrm{SD}=$ $.903)$.

Table 3: Analysis of Perception of Respondents about ECE Assessment

\begin{tabular}{|c|c|c|}
\hline Statement & Mean & SD \\
\hline $\begin{array}{l}\text { Early childhood assessment supports the individual educational } \\
\text { progress of children. }\end{array}$ & 3.62 & .506 \\
\hline $\begin{array}{l}\text { ECE assessment help to determine the suitable placement of } \\
\text { children. }\end{array}$ & 3.60 & .492 \\
\hline $\begin{array}{l}\text { ECE assessment provides information to parents regarding } \\
\text { their children's performance and progress. }\end{array}$ & 3.53 & .649 \\
\hline $\begin{array}{l}\text { ECE assessment facilitates the development of individual } \\
\text { educational planning and the curriculum in general. }\end{array}$ & 3.58 & .534 \\
\hline $\begin{array}{l}\text { ECE assessment identifies children with developmental } \\
\text { needs. }\end{array}$ & 3.55 & .608 \\
\hline $\begin{array}{l}\text { ECE assessment provides guidance in the referral of children } \\
\text { to specialist. }\end{array}$ & 3.55 & .616 \\
\hline Mean of Means and Standard Deviation & 3.57 & .350 \\
\hline
\end{tabular}

Table 3 presents the analysis of teachers' perception about assessment during early years' education of children. Data contained in the table shows that the teachers agreed that early childhood assessment supports individual educational progress of children (Mean $=3.62$; $\mathrm{SD}=.506$ ), helps determine suitable placement for children $(\mathrm{Mean}=3.60$; $\mathrm{SD}=$ .492), provides information to parents regarding their children's performance and 
progress $($ Mean $=3.53$; SD $=.649)$, facilitate development of individual educational planning and the curriculum in general (Mean $=3.58$; $\mathrm{SD}=.534$ ), identify children with developmental needs (Mean $=3.55 ; \mathrm{SD}=.608$ ) and provide guidance in referral of children to specialist (Mean $=3.55$; $\mathrm{SD}=.616$ ). It could also be observed that the discrete means of the respective items (statements) are higher than the calculated mean of means or average mean of 3.47. This result as depicted in Table 3 suggests and demonstrates that the teachers at the Tema West Metropolis have a positive perception about assessing children's learning and development during their early years' education.

\subsection{Analysis of Hypotheses}

$\mathbf{H}_{0}$ 1: There is no statistically significant difference in the perception of ECE teachers about early childhood assessment and their professional qualification in the Tema West Metropolis.

The first hypothesis $\left(\mathrm{H}_{0} 1\right)$ sought to compare teachers' perception and their professional qualifications in the Tema West Metropolis. Having subjected the dependent variable (teachers' perception) to normality test and homogeneity of equal variances, One Way ANOVA was used to test the first hypothesis.

Table 4: One Way ANOVA Results for Hypothesis two $\left(\mathrm{H}_{0} 2\right)$

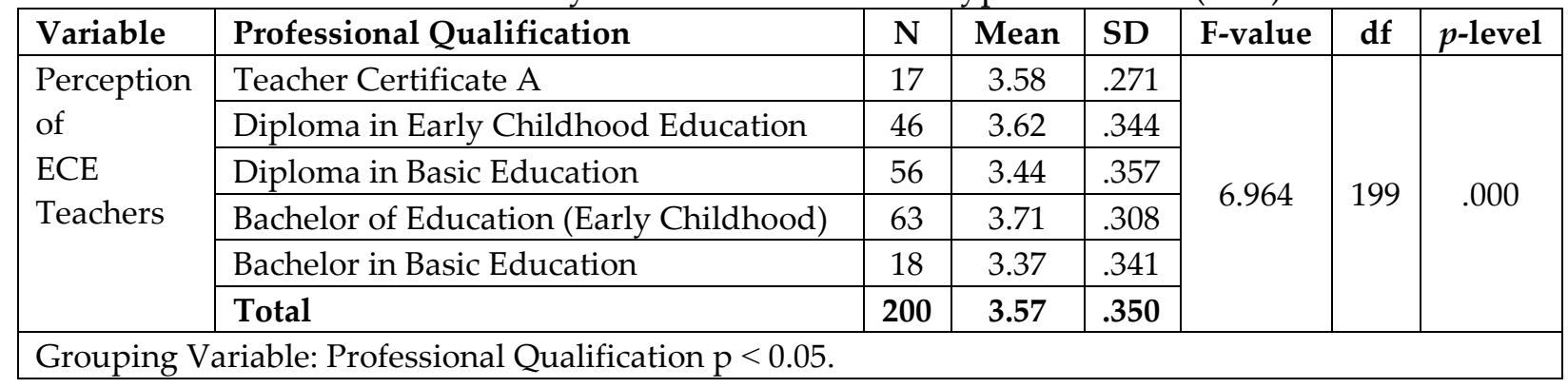

One-way ANOVA was conducted to determine whether or not there is a statistically significant difference in the perception of teachers and professional qualifications. The result shows that, there was a statistically significant difference across the various categories under teachers' professional qualification $(f$-value $=6.964 ; \mathrm{df}=199 ; p$-level $=$ $.000)$ in scores for Teacher's Certificate 'A' (Mean = 3.58, SD = .271), Diploma in Early Childhood Education (Mean =3.62, SD = .344), Diploma in Basic Education (Mean = 3.44, $\mathrm{SD}=.357$ ), Bachelor of Education in Early Childhood (Mean $=3.71, \mathrm{SD}=.308$ ) and Bachelor in Basic Education (Mean $=3.37, \mathrm{SD}=.341$ ). Since $p<0.05$, the null hypothesis was rejected while the alternative hypothesis was retained. This means that the perception of teachers in the Tema West Metropolis is not the same across professional qualifications of the teachers. In order words, the perception of teachers differs significantly across their professional qualifications.

Table 5 presents the Tukey HSD test of multiple comparison for the perception of teachers about ECE assessment based on their professional qualifications. The result shows that four (4) out of the twenty (20) pair groups had statistically significant 
differences in their perceptions about Early Childhood Education assessment with $p<0.05$. In particular, the result suggests that responses by teachers who had a Diploma in Basic Education are statistically different $(p<0.000)$ from those who had Bachelor of Education in Early Childhood. Also, the responses of teachers with Bachelor of Education in Early Childhood differs significantly $(p<0.000)$ from those with Diploma in Basic Education and Bachelor in Basic Education $(p<0.001)$. Furthermore, the analysis showed a significant $(p<0.001)$ difference between the perception ratings of teachers with a Bachelor in Basic Education and those with a Bachelor of Education in Early Childhood. However, there was no evidence of statistically significant differences between the other pair groups with $p>0.05$.

Table 5: Tukey HSD Test of Multiple Comparison

\begin{tabular}{|c|c|c|c|c|c|c|}
\hline $\begin{array}{l}\text { (I) Professional } \\
\text { Qualification }\end{array}$ & $\begin{array}{l}\text { (J) Professional } \\
\text { Qualification }\end{array}$ & Mean & $\begin{array}{l}\text { Std } \\
\text { Dev }\end{array}$ & $\begin{array}{c}\text { Mean } \\
\text { Diff. (I-J) }\end{array}$ & $\begin{array}{l}\text { Std. } \\
\text { Error }\end{array}$ & Sig. \\
\hline \multirow{4}{*}{$\begin{array}{c}\text { Teachers } \\
\text { Certificate } \\
\text { 'A' }\end{array}$} & $\begin{array}{c}\text { Diploma in Early } \\
\text { Childhood Education }\end{array}$ & 3.62 & .344 & -.041 & .094 & .992 \\
\hline & $\begin{array}{c}\text { Diploma in } \\
\text { Basic Education }\end{array}$ & 3.44 & .357 & .139 & .092 & .552 \\
\hline & $\begin{array}{l}\text { Bachelor of Education } \\
\text { (Early Childhood) }\end{array}$ & 3.71 & .308 & -.133 & .090 & .582 \\
\hline & $\begin{array}{c}\text { Bachelor in } \\
\text { Basic Education }\end{array}$ & 3.37 & .341 & .208 & .112 & .343 \\
\hline \multirow{4}{*}{$\begin{array}{l}\text { Diploma in } \\
\text { Early Childhood } \\
\text { Education }\end{array}$} & $\begin{array}{c}\text { Teachers } \\
\text { Certificate 'A' }\end{array}$ & 3.58 & .271 & .041 & .094 & .992 \\
\hline & $\begin{array}{c}\text { Diploma in } \\
\text { Basic Education }\end{array}$ & 3.44 & .357 & .180 & .066 & .052 \\
\hline & $\begin{array}{c}\text { Bachelor of Education } \\
\text { (Early Childhood) }\end{array}$ & 3.71 & .308 & -.092 & .064 & .606 \\
\hline & $\begin{array}{c}\text { Bachelor in } \\
\text { Basic Education }\end{array}$ & 3.37 & .341 & .249 & .092 & .056 \\
\hline \multirow{4}{*}{$\begin{array}{l}\text { Diploma in } \\
\text { Basic } \\
\text { Education }\end{array}$} & $\begin{array}{c}\text { Teachers } \\
\text { Certificate 'A' }\end{array}$ & 3.58 & .271 & -.139 & .092 & .552 \\
\hline & $\begin{array}{c}\text { Diploma in Early } \\
\text { Childhood Education }\end{array}$ & 3.62 & .344 & -.180 & .066 & .052 \\
\hline & $\begin{array}{l}\text { Bachelor of Education } \\
\text { (Early Childhood) }\end{array}$ & 3.71 & .308 & $-.272^{*}$ & .061 & .000 \\
\hline & $\begin{array}{c}\text { Bachelor in } \\
\text { Basic Education }\end{array}$ & 3.37 & .341 & .069 & .090 & .939 \\
\hline \multirow{4}{*}{$\begin{array}{c}\text { Bachelor of } \\
\text { Education } \\
\text { (Early Childhood) }\end{array}$} & $\begin{array}{c}\text { Teachers } \\
\text { Certificate 'A' }\end{array}$ & 3.58 & .271 & .133 & .090 & .582 \\
\hline & $\begin{array}{c}\text { Diploma in Early } \\
\text { Childhood Education }\end{array}$ & 3.62 & .344 & .092 & .064 & .606 \\
\hline & $\begin{array}{c}\text { Diploma in } \\
\text { Basic Education }\end{array}$ & 3.44 & .357 & $.272^{*}$ & .061 & .000 \\
\hline & $\begin{array}{c}\text { Bachelor in } \\
\text { Basic Education }\end{array}$ & 3.37 & .341 & $.341^{*}$ & .088 & .001 \\
\hline $\begin{array}{c}\text { Bachelor in } \\
\text { Basic Education }\end{array}$ & $\begin{array}{c}\text { Teachers } \\
\text { Certificate 'A' }\end{array}$ & 3.58 & .271 & -.208 & .112 & .343 \\
\hline
\end{tabular}




\begin{tabular}{|l|c|c|c|c|c|c|}
\hline \hline \multirow{5}{*}{} & $\begin{array}{c}\text { Diploma in Early } \\
\text { Childhood Education }\end{array}$ & 3.62 & .344 & -.249 & .092 & .056 \\
\cline { 2 - 7 } & $\begin{array}{c}\text { Diploma in } \\
\text { Basic Education }\end{array}$ & 3.44 & .357 & -.069 & .090 & .939 \\
\cline { 2 - 7 } & $\begin{array}{c}\text { Bachelor of Education } \\
\text { (Early Childhood) }\end{array}$ & 3.71 & .308 & $-.341^{*}$ & .088 & .001 \\
\hline
\end{tabular}

$\mathrm{H}_{0}$ 2: There is no statistically significant difference in the perception of male and female ECE teachers about early childhood assessment in the Tema West Metropolis.

The second hypothesis $\left(\mathrm{H}_{0} 2\right)$ sought to compare male and female teachers' perception about assessment in early grade education within the Tema West Metropolis. Independent-Samples T-test was used to test this hypothesis.

The result from the independent-samples t-test conducted shows that there were no statistically significant differences $(\mathrm{df}=198 ; \mathrm{t}=1.236 ; p=.218$ ) in scores for Males (Mean $=3.63 ; \mathrm{SD}=.344)$ and Female (Mean $=3.55 ; \mathrm{SD}=.351)$ teachers. The null hypothesis was therefore retained while the alternative hypothesis was rejected. This means that the perception of teachers about assessment in early grade education within the Tema West Metropolis is the same across male and female categories. In other words, there is no difference in the perception of teachers.

Table 6: Independent-Samples T-test Results for Hypothesis 2

\begin{tabular}{|c|c|c|c|c|c|c|c|c|c|}
\hline & Sex & $\mathbf{N}$ & Mean & SD & \multicolumn{5}{|c|}{ T-test for Equality of Means } \\
\hline \multirow{4}{*}{$\begin{array}{l}\text { Assessment } \\
\text { Practices of } \\
\text { Teachers }\end{array}$} & & & & & $\mathbf{t}$ & df & Sig. (2-tailed) & $\begin{array}{c}\text { Mean } \\
\text { Diff. }\end{array}$ & $\begin{array}{c}\text { Std. Error } \\
\text { Diff. }\end{array}$ \\
\hline & & & & & 1.236 & 198 & .218 & .071 & .058 \\
\hline & Male & 49 & 3.63 & .344 & & & & & \\
\hline & Female & 151 & 3.55 & .351 & & & & & \\
\hline
\end{tabular}

Dependent Variable: Teachers' Perception a. Grouping Variable: Sex, $\mathrm{p}>0.05$.

\section{Discussion}

It has emerged from the analysis of data gathered regarding research question one that the teachers in the Tema West Metropolis have an understanding of Early Childhood Education (ECE) assessment practices which suggests an indication that the teachers have some level of training. This was demonstrated as the responses of the teachers among others indicated that ECE assessment needs to be age and linguistically appropriate, should help pupils to make account of their learning progress and the overall purpose of ECE assessment must be to determine whether pupils have mastered a learning objective or not. This finding agrees with Khurshid (2008) who also observed that, if a specially trained teacher teaches a group of learners, the performance of the learners is usually good and high because, in the process of education, the teacher is very crucial. Similarly, Siegel (1987) stated that due to the many functions performed by the ECE teacher; he/she must possess a certain quality of education, greater theoretical knowledge of child 
development and learning. Clark-Stewart (1984) confirmed that early childhood teachers or administrators who provide high-quality Early Childhood Education programme must possess certain specific training in child development and learning. Despite this understanding, however, the teachers still believe that ECE assessment is just to prepare children for standardized examinations only.

Analysis of the second research question revealed that teachers who deliver ECE in the Tema West Metropolis possess positive perceptions about the need for assessing children during their early years' education. This was shown from the analysis of responses given by the teachers which indicated that ECE assessment supports individual educational progress of children, helps determine suitable placement for children as well as provides information to parents regarding their children's performance and progress. Furthermore, the teachers believe that Early Childhood Education assessment facilitates the development of individual educational planning and the curriculum, in general, helps identify children with developmental needs and provides guidance in the referral of children to a specialist. This aligns with the findings of an earlier study conducted by Goodrum, Hackling, and Rennie (2001) who in their study concluded that assessment is a key component of the teaching and learning process and hence, including students' and teachers' perceptions in designing assessment tools would be considered reasonable, given the fact that both students' preferences and teachers' rationale might influence the way students proceed with learning and the way it is tested. In a similar vein, a study conducted by Cavangah, Waldrip, Romanoski, Fisher, and Dorman (2005) indicated that assessment forms and tasks selected by teachers and administrators depend on their perceptions of assessment which suggest that perception of teachers is vital as far as assessment in ECE is concerned. Roos and Hamilton (2005) therefore cautioned that teachers must perceive the value of assessment to go far beyond playing a role in the self-regulation of human learning but also being able to support human development.

The results from the hypothesis also showed that there is no statistically significant difference in the perception of ECE teachers and gender. The second hypothesis however indicated that the perception of ECE teachers differs significantly across their professional qualifications. Specifically, the result suggests that responses of teachers who had Diploma in Basic Education are statistically different from those who had Bachelor of Education in Early Childhood, the responses of teachers with Bachelor of Education in Early Childhood differ significantly from those with Diploma in Basic Education and Bachelor in Basic Education and finally, there is a significant difference between the perception ratings of teachers with Bachelor in Basic Education and those with a Bachelor of Education in Early Childhood.

\section{Conclusions}

It was evidenced from the analysis of research question one that, teachers who deliver Early Childhood Education in the Tema West Metropolis have some level of knowledge 
about how to assess children which suggested that they have some level of training. Also, it was evidenced with respect to research question two that, teachers in the municipality hold a positive perception about Early Childhood Education assessment and the need to assess children during early years' education. This implies that the teachers understand the benefits children derived from effective and appropriate assessment practices in Early Childhood Education. Finally, while the perception of ECE teachers differs significantly across their professional qualifications, there was no statistically significant difference in their perception about assessment in early years education and gender.

\subsection{Recommendations}

Although the findings show that Early Childhood Education teachers in the Tema West Metropolis possess some level of knowledge about how to assess children during their early years' education, it is recommended that the educational directorate in the metropolis through the help of the Ghana Education Service (GES) should ensure continuous professional development in the form of in-service training for the teachers. This will help abreast their knowledge and assessment practices in the metropolis. Again, it is recommended that the educational directorate, School Management Committee (SMC), Parent Association (PA) among others in the metropolis should encourage and motivate the teachers through active participation in the activities of the children in the school. This will help teachers to be more committed to using appropriate assessment practices in assessing children in the schools within the Tema West Metropolis.

\section{Conflict of Interest Statement}

The authors declare no conflicts of interest.

\section{About the Authors}

Agnes Amoah obtained a bachelor's degree in Early Childhood Education from the University of Education, Winneba. She is an early childhood educator. Her research interest focuses on monitoring and practices in early childhood settings. He is currently pursuing a Master of Philosophy Degree in Early Childhood Education.

Dr. Yayra Dzakadzie is a Senior Lecturer in the Department of Early Childhood Education, Faculty of Educational Studies, University of Education, Winneba, Ghana. He is currently the Vice Dean of the Faculty of Educational Studies, University of Education, Winneba.

Seth Agbayisah obtained a Master of Philosophy in Early Childhood Education. He is currently a Tutor Agogo Presbyterian Women's College of Education, Asante AkyemAgogo. 


\section{References}

Amponsah, M. (2004). The status of coordination and supervision of early childhood education in Ghana. Unpublished master's major project report. Victoria: University of Victoria, Canada.

Bagnato, S. J., McLean, M., Macy, M., \& Neisworth, J. T. (2011). Identifying instructional targets for early childhood via authentic assessment: Alignment of professional standards and practice-based evidence. Journal of Early Intervention, 33(4), 243-253.

Betts, J. R., Zau, A., \& Rice, L. (2003). Determinants of student achievement: New evidence from San Diego. San Francisco: Public Policy Institute of California.

Bowman, B. T. Donovan, M. S \& Burns, M. S (eds.) (2001). Eager to Learn: Educating our Preschoolers. Committee on Early Childhood Pedagogy, 55-71.

Bronson, M. B. (1994). The usefulness of an observational measure of young children's social and mastery behaviours in early childhood classrooms. Early Childhood Research Quarterly,9(1), 19-43.

Cavanagh, R. F., Waldrip, B. G., Romanoski, J. T., Fisher, D. L., \& Dorman, J. P. (2005). Measuring student perceptions of classroom assessment. Annual meeting of the Australian Association for Research in Education. Parramatta, Australia: Australian Association for Research in Education.

Chester, C., \& Quilter, S. (1998). In-service teachers' perceptions of educational assessment. Journal for Research in Mathematics Education, 33 (2), 210-236.

Clark-Stewart, K. A. (1984). Day care: A new context for research and development. The Minnesota symposia on child psychology. Hillsdale, New Jersey: Lawrence Erlbaum Associates.

Copple, C., \& Bredekamp, S. (2006). Basics of developmentally appropriate practice: An introduction for teachers of children 3 to 6. Washington, DC: National Association for the Education of Young Children.

Dornyei, Z., \& Taguchi, T. (2010). Questionnaires in Second Language Research: Construction, Administration, and Processing (2nd ed.). New York: Routledge.

Duffy, B. (2010). The early years curriculum. In G. Pugh \& B. Duffy (Eds.), Contemporary issues in the early years (pp. 95-108). London: SAGE Publications.

Ellis, A. K. (2014). Research on educational innovations. Routledge, USA

Fennema, E., \& Romberg, T. (1999). Mathematics classrooms that promote understanding. New Jersey: Lawrence Erlbaum Associates.

Forrester, R. (2008). The assessment of newly qualified teachers' beliefs about the teaching and learning of mathematics. Informal Proceedings of the British Society for Research into Learning Mathematics (BSRLM), 28(2), 10-17.

Goodrum, D., Hackling, M., \& Rennie, L. (2001). The status and quality of teaching and learning of science in Australian schools. Canberra: Department of Education, Training and Youth Affairs. 
Goodwin, A. L. (2000). Honoring ways of knowing. Equity Resource Center Digest on Education Assessment. Newton, MA: Women's Educational Equity Act Resource Center.

Gulikers, J., Bastiaens, T., Kirschner, P., \& Kester, L. (2006). Relations between students' perceptions of assessment authenticity, study approaches, and learning outcome. Studies in Educational Evaluation, 32 (4), 381-400.

Horton, C., \& Bowman, B. T. (2002). Child Assessment at the Preprimary Level: Expert Opinion and State Trends. Occasional Paper.

Khurshid, K. (2008). A study of the relationship between the professional qualifications of the teachers and academic performance of their students at secondary school level. World Academy of Science, Engineering and Technology, 38(2), p445-451.

Okewole, J. O., Iluezi-Ogbedu, V. A., \& Osinowo O. A. (2015). An evaluation of the implementation of early childhood education curriculum in Osun State. Journal of Education and Practice, 6(4), 48-54.

Osho, L. O., Aliyu, N., Okolie, O., \& Onifade, O. (2013). Implementation of early childhood education: A case study in Nigeria. Universal Journal of Educational Research 2(2), 119-125.

Pellegrino, J. W., \& Goldman, S. R. (2008). Beyond rhetoric: Realities and complexities of integrating assessment into classroom teaching and learning. In C. A. Dwyer (Eds). The future of assessment: Shaping teaching and learning (pp. 53-82). New York: Lawrence Erlbaum Associates.

Puckett, M. B., \& Black, J. K. (2000). Authentic assessment of the young child: Celebrating development and learning. Prentice-Hall Order Processing Center, PO Box 11071, Des Moines, IA 50336-1071.

Roos, B., \& Hamilton, D. (2005). Formative assessment: A cybernetic viewpoint. Assessment in Education: Principles, Policy E Practice, 12 (1), 7-20.

Schappe, J. F. (2005). Early childhood assessment: A correlational study of the relationships among student performance, student feelings, and teacher perceptions. Early Childhood Education Journal, 33(3), 187-193.

Siegel, H. (1987). Relativism refuted: A critique of contemporary epistemological relativism. Dordrecht: Reidel.

Sokopo, Z. N. (2004). The interactional effects of different assessment policies on the culture of learning and teaching. University of Pretoria. Pretoria: Unpublished Doctor of Education (D Ed) dissertation.

Soto, L. D., \& Swadener, B. B. (2002). Toward liberatory early childhood theory, research and praxis: Decolonizing a field. Contemporary issues in early childhood, 3(1), 38-66.

Trevarthen, C. (2002). Origins of musical identity: Evidence from infancy for musical social awareness. Musical identities, 21-38.

Williams, D. D. (1996). Environmental constraints in temporary fresh waters and their consequences for the insect fauna. Journal of the North American Benthological Society, 15(4), 634-650. 
Agnes Amoah, Yayra Dzakadzie, Seth Agbayisah

Creative Commons licensing terms

Author(s) will retain the copyright of their published articles agreeing that a Creative Commons Attribution 4.0 International License (CC BY 4.0) terms will be applied to their work. Under the terms of this license, no permission is required from the author(s) or publisher for members of the community to copy, distribute, transmit or adapt the article content, providing a proper, prominent and unambiguous attribution to the authors in a manner that makes clear that the materials are being reused under permission of a Creative Commons License. Views, opinions and conclusions expressed in this research article are views, opinions and conclusions of the author(s). Open Access Publishing Group and European Journal of Education Studies shall not be responsible or answerable for any loss, damage or liability caused in relation to/arising out of conflicts of interest, copyright violations and inappropriate or inaccurate use of any kind content related or integrated into the research work. All the published works are meeting the Open Access Publishing requirements and can be freely accessed, shared, modified, distributed and used in educational, commercial and non-commercial purposes under a Creative Commons Attribution 4.0 International License (CC BY 4.0). 